\title{
BEING CHRISTIANS IN THE ACEHNESE WAY Illiberal Citizenship and Women's Agency in the Islamic Public Sphere
}

\author{
Muhammad Ansor | IAIN Langsa, Aceh - Indonesia \\ Yaser Amri | IAIN Langsa, Aceh - Indonesia \\ Corresponding author: yaser.amri@gmail.com
}

\begin{abstract}
This article examines the ways in which Acehnese Christian women's identities expressed in the Islamic public sphere. The article argues that although theoretically Islamic Shari'a only applies to Muslims, its implementation in Aceh has a significant impact on the daily life of Christian women. The first part of the article presents a critical review regarding the Islamic sharia in Aceh dealing with the discourse of citizenship and the position of non-Muslim. Furthermore, drawing on agency theoretical frameworks, the authors describe the experiences of Christian women from diverse backgrounds to show how they became Christians in the Acehnese way. The article finally shows that Christian women's agencies as a minority in Aceh face a critical situation, although they remain independent and are not easily subdued by public sphere driven by the values and religious identities of the majority.
\end{abstract}

Keywords: Woman agency, Aceh Christian, Islamic public sphere

\section{Introduction}

Although theoretically Islamic Shari'a only applies to Muslims, its implementation has a significant impact on the daily life of Christian women. In Aceh, for example, a number of Qanun directly have its impact to the Christian women's life such as the regulation of Islamic dress code (Qanun No. 11/2002), restriction on the construction of worship places apart from the mosque (Qanun No. 4/2016), and the prohibition for non-Muslim to hold religious activities outside the worship places (Qanun No. 4/2016). In this sense, the intersection between subject and structure is a channel to reproduce the diverse 
experiences among Aceh Christian women. This paper discusses these experiences in the context of citizenship, women's agency, and Islamic public sphere.

The scholarly focus on citizenship states that every citizen is free and equal. ${ }^{1}$ Therefore, when Islamic political discourse is linked to the concept of citizenship, contemporary Islamist proponents "provide theoretical justification for citizenship", but the question is "what kind of citizenship remains". ${ }^{2}$ This is because the mainstream of Islamic political discourse is still dominated by the concept of dhimma which affirms the differences of rights and obligations among Muslim and non-Muslim citizens. ${ }^{3}$

The concept of agency is used for examining the negotiation of Christian identity as citizen, woman, and Christian as well. The discourse on women and agency at least divided into three contingent of thought. In the first contingent is the theory of feminists like Judith Butler and Susan Moller Okin whose conceptualized agency as liberation from religious ties, culture, and other social norms. Agency is almost always derived from, and directed at, the articulation of resistance to social norms and the subordinating function of power. ${ }^{4}$ Okin suggest, "women should not be disadvantaged by their sex, that they should be recognized as having human dignity equal to that of men, and that they should have the opportunity to live as fulfilling and as freely chosen lives as men can". 5 Agency is explored "as a strategic response to structures domination". ${ }^{6}$

1 Will Kymlicka, Multicultural Citizenship: A Liberal Theory of Minority Rights (New York: Oxford University Press, 1995), p. 34.

2 Rachel M. Scott, The Challenge of Political Islam: Non-Muslims and the Egyptian State (Stanford, California: Stanford University Press, 2010), p. 148.

3 Rachel M Scott, "Contextual Citizenship in Modern Islamic Thought," Islam and Christian-Muslim Relations, 18, no. 1 (2007), pp. 2-5.

${ }^{4}$ Judith Butler, Exitable Speech: A Politics of Pervormative (New York: Routledge, 1997), p. 17; Judith Butler, Gender Trouble: Feminism and the Subversion of Identity (New York: Taylor and Francis e-Library, 1999).

5 Susan Moller Okin, "Is Multiculturalism Bad for Women?," in Is Multiculturalism Bad for Women?, ed. Joshua Cohen, Matthew Howard, and Martha C. Nussbaum (Princeton: Princeton University Press, 1999), pp. 8-24.

6 Subrata K. Mitra, "Introduction: Citizenship as Cultural Flow-Shifting Paradigms, Hybridization, or Plus ca Change?," in Citizenship as Cultural Flow: Structure, Agency and Power, ed. Subrata K. Mitra (London: Springer, 2013), p. 2. 
In the second contingent of thought, feminist scholars such as Lila Abu-Lughod, Saba Mahmood, and Orit Avishai propose that women in the east are agentive in ways that differ from conventional western notions of agency. ${ }^{7}$ Agency must be understood as a capacity for action that is contextually contingent, located within structures of power rather than outside them. 8 Through her ethnography, Mahmood "restated" the liberal assumptions that women are inherently predisposed to seek emancipation from Islamic revivalism, or at least to suggest that they ought to. ${ }^{9}$ Orit Avishai uses the term "doing religion" to describe agency articulations that are based on adherence to religious norms and traditions. ${ }^{10}$

Apart from these two contingents arises third contingent which combine pious and critical as an another agency. Based on his study on Fatayat NU and Rahima in post-reform Indonesia, Rachel Rinaldo introduced the concept of pious critical agency. ${ }^{11}$ According to Rinaldo, it is the capacity to engage critically and publically with religious texts. For Rinaldo, the pious critical agency is similar to Mahmood's pious agency in that it captures how an individual's attempt to live up to religious norms can be a form of agency. ${ }^{12}$ However, it also encapsulates a different process than what Mahmood describes because women try to be virtuous religious subjects through a critical approach to religion.

\footnotetext{
7 Lila Abu-Lughod, "Do Muslim Women Really Need Saving? Anthropological Reflections on Cultural Relativism and Its Others," American Anthropologist, 104, 3 (2002), pp. 783-790; Orit Avishai, “Doing Religion' in a Secular World: Women in Conservative Religions and the Question of Agency," Gender \& Society, 22, no. 4 (2008), pp. 409-433; Saba Mahmood, Politics of Piety: The Islamic Revival and the Feminist Subject (Princeton: Princeton University Press, 2005).

8 Mahmood, Politics of Piety: The Islamic Revival and the Feminist Subject.

9 Julius Bautista, "The Meta-Theory of Piety: Reflections on the Work of Saba Mahmood," Contemporary Islam, 2, no. 1 (2008), pp. 78-79.

10 Avishai, “Doing Religion' in a Secular World: Women in Conservative Religions and the Question of Agency."

11 Rachel Rinaldo, "Pious and Critical: Muslim Women Activists and the Question of Agency," Gender \& Society, 20, no. 10 (2014), p. 6.

12 Rachel Rinaldo, "Women and Piety Movements," in The New Blackwell Companion to the Sociology of Religion, ed. Bryan S. Turner (United Kingdom: Wiley-Blackwell, 2010), pp. 584-605.
} 
The discourse above shows the differentiation of women agency as something rigid and clear. This article proposes a different view. By means of Acehnese Christian women's experience, the three dichotomic concepts of agency are blurred and lost its clear-cut. As will be discussed, the policies of Islamic dress in Aceh that was responded by Christian women in various ways as a form of expression of identity and respect for the Islamic Shari'a; is essentially an agency articulation. Whatever the response of Christian women to the structure of the Islamic public sphere is actually an achievement of agency as far as it is based on the "capacity to make choices and take action". ${ }^{13}$ Anthony Giddens reveals that the notion of agency is intrinsically linked with that of power, meaning not only the ability to choose but also the ability to choose otherwise. ${ }^{14}$ According to AbuLughod, veiling or not veiling "must not be confused with, or made to stand for, lack of agency". 15

Based on observation and semi-structured interviews with twenty women in two major cities in Aceh, i.e. Langsa and Banda Aceh during 2013-2017, the author shows the complexity of Christian women agency as the result of a negotiation between "external social structures and subjective experiences". ${ }^{16}$ This subject is not a new theme because the intersection between structure and agency has been examined by various scholars in different fields. ${ }^{17}$ Apart from discussing the agency through interfaith interaction, however, this article shows that in the

13 Rinaldo, "Pious and Critical: Muslim Women Activists and the Question of Agency"; Muhammad Ansor, "Post-Islamism and the Remaking of Islamic Public Sphere in Post-Reform Indonesia," Studia Islamika, 23, no. 3 (2016), pp. 471-515.

14 Anthony Giddens, The Constitution of Society: Outline of the Theory of Structuration (Cambridge: Polity Press, 1984), p. 9.

15 Lila Abu-Lughod, Do Muslim Women Need Saving? (Cambridge: Harvard University Press, 2013), p. 39.

16 Michael Janoschka, "Habitus and Radical Reflexivity: A Conceptual Approach to Study Political Articulations of Lifestyle- and Tourism- Related Mobilities," Journal of Policy Research in Tourism, Leisure \& Events, 3, 3 (2011), p. 225.

17 Sarab Abu-Rabia-Queder and Naomi Weiner-Levy, "Between Local and Foreign Structures: Exploring the Agency of Palestinian Women in Israel," Social Politics, 20, 1 (2013), p. 90; Jennifer Fleetwood, "Narrative Habitus: Thinking through Structure/Agency in the Narratives of Offenders," Crime Media Culture, 12, no. 2 (2016), pp. 173-192. 
midst of liminality, Acehnese Christian women were capable to articulate multiple agencies.

\section{Aceh's Sharia, Christian and Illiberal Citizenship}

Many scholars discuss the implementation of Islamic law in Aceh. Arskal Salim, ${ }^{18}$ Hasnil Basri Siregar, ${ }^{19}$ Moch. Nur Ichwan, ${ }^{20}$ and R. Michael Feener ${ }^{21}$ discuss constitutional dimension, sociological and political, in relation to the implementation of Islamic sharia in Aceh. David Kloos presents an ethnography of village citizens in Banda Aceh which makes Islamic sharia as a basis of norms and values to reawakening after the conflict and Tsunami. ${ }^{22}$ Dina Afrianty, ${ }^{23}$ Kristina Großmann, ${ }^{24}$ Muhammad Ansor, ${ }^{25}$ and Reed Taylor 26

18 Arskal Salim, Challenging the Secular State: The Islamization of Law in Modern Indonesia (Honolulu: University of Hawai'i Press, 2008).

19 Hasnil Basri Siregar, "Lessons Learned from the Implementation of Islamic Shari'ah Criminal Law in Aceh, Indonesia," Journal of Law and Religion, 24, 1 (2008), pp. 143-176.

20 Moch. Nur Ichwan, "Official Ulema and the Politics of Re-Islamization: The Majelis Permusyawaratan Ulama, Shari'atization and Contested Authority in Post-New Order Aceh," Journal of Islamic Studies, 22, 2 (2011), pp. 183-214.

21 R. Michael Feener, "State Shari'a and Its Limits," in R. Michael Feener, David Kloos, and Annemarie Samuels (eds), Islam and the Limits of the State: Reconfigurations of Practice, Community and Authority in Contemporary Aceh (Leiden: Brill, 2016), pp. 1-23; R. Michael Feener, Shari'a and Social Engineering: The Implementation of Islamic Law in Contemporary Aceh, Indonesia (Oxford: Oxford University Press, 2013).

22 David Kloos, Becoming Better Muslims: Religious Authority and Ethical Improvement in Aceh, Indonesia (Princeton and Oxford: Princeton University Press, 2018).

23 Dina Afrianty, "Local Women's NGOs and the Reform of Islamic Law in Aceh: Case of MISPI," in Feener, Kloos, and Samuels (eds), Islam and the Limits of the State, pp. 118-140; Dina Afrianty, Women and Sharia Law in Northern Indonesia: Local Women's NGOs and the Reform of Islamic Law in Aceh (London: Routledge, 2015).

24 Kristina Grossmann, "Muslim Female Activists and Sharia in Indonesia: Scopes of Acting in National and International Perspectives," Review of Indonesian and Malaysian Affairs, 48, 1 (2014), pp. 95-125; Kristina Grossmann, "Women's Rights Activists and the Drafting Process of the Islamic Criminal Law Code (Qanun Jinayat)," in Feener, Kloos, and Samuels (eds), Islam and the Limits of the State, pp. 87-117.

25 Muhammad Ansor, "Being Woman in the Land of Shari'a: Politics of the Female Body, Piety and Resistance in Langsa, Aceh," Al-Jami'ah, 52, 1 (2014), pp. 59-83; Muhammad Ansor and Yaser Amri, "Beyond Pious Critical Agency: Women, Interfaith Marriage and Religious Conversion In Aceh," Analisa, 1, 2 (2016), pp. 217238. 
discuss gender relations and women's negotiation towards Islamic sharia of Aceh. Reza Idria ${ }^{27}$ discusses cultural resistance to the Islamic sharia of Aceh. The authors are not in the position to repeat the discussions above but explore an aspect which is ignored and has less attention from scholars, that is non-Muslim's experiences in Aceh.

Antagonistic relation between Muslim and non-Muslim in Aceh can be traced from the colonial period. Ismatu Ropi said that in the XVII century some eminent scholars, like Nuruddin ar-Raniry (d. 1658) had written a polemic that discredited Christian as deviated religion and misguide people. ${ }^{28}$ Arskal Salim, ${ }^{29}$ Kamaruzzaman Bustamam-Ahmad, ${ }^{30}$ and Siregar, ${ }^{31}$ describe that Aceh Islamic identity has a significant role in evoking resistance against the Dutch colonial (1873-1903) which is associated as unbeliever (kafir). ${ }^{32}$ The idea of a Sabil war is great propaganda that not only contributed to the rise of resistance against the Dutch ${ }^{33}$ but also succeeded in establishing firm boundaries between Muslims and non-Muslims. The presence of non-Muslims from different parts of the world to take part

26 Reed Taylor, "Syariah as Heterotopia: Responses from Muslim Women in Aceh, Indonesia," Religions, 6, 2 (2015), pp. 566-593; Reed W. Taylor, “A Postcolonial Inquiry of Women's Political Agency in Aceh, Indonesia: Towards a Muslim Feminist Approach?” (Virginia Polytechnic Institute and State University, 2012).

27 Reza Idria, "Cultural Resistance to Shariatism in Aceh," in Islam, Politics and Change: The Indonesian Experience after the Fall of Subarto, ed. Kees van Dijk and Nico J.G. Kaptein (Leiden: Leiden University Press, 2016), pp. 247-268.

28 Ismatu Ropi, "Muslim-Christian Polemics in Indonesian Islamic Literature," Islam and Christian-Muslim Relations, 9, 2 (1998), pp. 218-220.

29 Arskal Salim, “'Sharia from below' in Aceh (1930s-1960s): Islamic Identity and the Right to Self-Determination with Comparative Reference to the Moro Islamic Liberation Front (MILF)," Indonesia and the Malay World, 32, 92 (2004), pp. 83-84.

30 Kamaruzzaman Bustamam-Ahmad, "The Application of Islamic Law in Indonesia: The Case Study of Aceh,” Journal of Indonesian Islam, 1, 1 (2007), pp. 135-180.

31 Siregar, "Lessons Learned from the Implementation of Islamic Shari'ah Criminal Law in Aceh, Indonesia."

32 Ibrahim Alfian, Sastra Perang: Sebuah Pembicaraan Mengenai Hikayat Perang Sabil (Jakarta: Balai Pustaka, 1992); Jesse Hession Grayman, "We Build Our Own Stories': The 19-Th-Century Figure and 21st-Century Myth of the Acehnese Poet Dokarim," Indonesia 99 (2015), pp. 51-65.

33 Paul van 't Veer, Perang Aceh: Kisah Kegagalan Snouck Hurgronje (Jakarta: Grafiti Press, 1985). 
in the post-Tsunami reconstruction of Aceh does not seem to reduce the negative image of non-Muslims in the Acehnese cultural sense. ${ }^{34}$

The contemporary social construction of Acehnese Christians can be traced by reviewing the laws and canons concerning the Islamic Shari'a of Aceh; and their daily dynamics in the Islamic public sphere of Aceh. ${ }^{35}$ The constitution of Aceh states that Muslim and nonMuslim citizens are basically equal before the law, politics, and social. Chapter 212 verse (1) ordinance No. 11/2006 about Aceh government states that Aceh citizen is "one who lives permanently in Aceh regardless of his tribe, race, religion, and family line". Chapter 127 mentioned that the government of Aceh guarantees religious freedom and protecting the rights of any religious adherents to practice their religious practices according to their religion. Qanun No. 5/2000 about the implementation of Islamic sharia says that other religions of nonIslam have remained recognized in the region, its adherents may practice the teachings of their respective religions (Chapter 2 verse [2]). ${ }^{36}$

But there are many clues that the idea of citizenship in the Qanun of the Islamic Sharia of Aceh contradicts the principles of justice, equality, and freedom. Qanun No. 6/2014 about the criminal law says that non-Muslims who commit crimes that are not regulated in the Criminal Code may subject themselves to the Qanun of Jinayah (Chapter 5). Qanun No. 8/2015 about the guidance and protection of the faith (pembinaan dan perlindungan Aqidah) regulates the severe penal sanction for apostacy (Chapter 7, 18). Qanun No. 4/2016 about guidelines for maintaining religious harmony and the establishment of worship places (Pedoman Pemeliharaan Kerukunan Umat Beragama dan Pendirian Tempat Ibadab), to some extends affirming inequality and lack of freedom of Acehnese citizen (Chapter 13-18). Qanun regulates requirements for the establishment of non-Muslim worship places with

34 Jesse Hession Grayman, "Humanitarian Encounters in Post-Conflict Aceh, Indonesia" (Unpublished Doctoral Dissertation, Harvard University, 2012).

35 Muhammad Ansor, Yaser Amri, and Ismail Fahmi Arrauf, "Under the Shadow of Sharia: Christian Muslim Relations from Acehnese Christian Experience," Komunitas, 8, 1 (2016), pp. 125-134.

36 Melissa Crouch, "Implementing the Regulation on Places of Worship in Indonesia: New Problems, Local Politics and Court Action," Asian Studies Review, 34, 4 (2010), pp. 403-419. 
a regulation which is not applied to the establishment of Muslim worship place (Chapter 19). Qanun also have a regulation about the prohibiton of Non-Muslim to hold religious activities outside the worship places, a regulation which is not applied to Muslim.

The restriction of church construction in Aceh has been going on for a long time. ${ }^{37}$ Moreover, it has been recorded that some conflicts and social violence occurred in Aceh due to this problem. One of the earliest violent incidents relating to a place of worship in postindependence Indonesian history occurred in Meulaboh in Aceh in July 1967, where a Muslim mob burned down a church. ${ }^{38}$ In 1979, a conflict between Muslims and Christians resulted in the burning of six churches in Aceh Singkil.39 The conflict took place again after the implementation of Islamic sharia, that is in 2001, 2006, $2012^{40}$ and culminated in October 2015 resulting in lost of one's live and the ban of ten churches in Aceh Singkil. ${ }^{41}$ Two years before the incident in Aceh Singkil, that was in the midst of 2013, The congregation of Indonesia Bethel Church in Banda Aceh was also attacked because the building the used as worship place does not have permit. ${ }^{42}$

The prohibition for non-Muslim to do religious activities outside the worship places impact to the daily life of Acehnese Christian. The consequence of this regulation is the prohibition for schools in Aceh to teach religious lesson other than Islam. When the subjects of Islam taught in the classroom, non-Muslim students are free to remain in the

37 Miswari, "Mu'ḍilat Al-Aqlīyah Al-Masīhịyah Fī Hudūd Balad Al-Sharī'ah AlIslāmīyah," Studia Islamika, 25, 2 (2018), p. 351.

38 Jan Sihar Aritonang and Karel Steenbrink, A History of Christianity in Indonesia (Leiden and Boston: Brill, 2008); Mujiburrahman, Feeling Threatened: Muslim-Christian Relations in Indonesia's New Order (Leiden: Amsterdam University Press, 2006); Ismatu Ropi, Religion and Regulation in Indonesia (Singapore: Palgrave Macmillan, 2017).

39 Muhammad Ansor, "We Are from the Same Ancestors': Christian-Muslim Relations in Contemporary Aceh Singkil," Al-Albab, 3, 1 (2014), pp. 12-15.

40 Deny Setiawan and Bahrul Khoir Amal, "Membangun Pemahaman Multikultural Dan Multiagama Guna Menangkal Radikalisme Di Aceh Singkil," Al-Ulum, 16, 2 (2016), p. 363.

41 Teuku Kemal Fasya, "Memperbaiki Keberagamaan Singkil," Kompas (Jakarta, 2015), p. 7.

42 Al Makin, "Islamic Acehnese Identity, Sharia, and Christianization Rumor: A Study of the Narratives of the Attack on the Bethel Church in Penauyong Banda Aceh," Journal of Indonesian Islam, 10, 1 (2016), pp. 11-16. 
classroom to receive Islamic teachings, or temporarily leave the class during the lesson. Likewise, non-Muslim students at some universities in Aceh taught only Islamic subjects. Samudra University authorities said that they will not hold lectures of religious teachings other than Islam because it is contrary to the principle of Aceh's privileges as a sharia province. ${ }^{43}$ In contrast to the religious activities of Muslims who have the support and facilitation of the government; non-Muslims have no space to deepen their religion apart from regular activities undertaken in worship places.

Other issues that have a significant impact on the daily life of Christians are the regulation of the necessity of Islamic dress, and the requirements of public leaders in Aceh (from the level of the governor to the village head) one of the requirements is the capability to practice the religion of Islam. The regulation of Islamic dress is the issue that attracted mostly public attention related to the implementation of Islamic Sharia in Aceh. ${ }^{44}$ Chapter 13 Qanun No. 11/2002 about the implementation of Islamic sharia in the field of Aqidah, Ibadah, dan Syi'ar stated that every Muslim is obliged to dress accordingly to Islamic dress code (verse 1); and "the heads of government agencies, educational institutions, business entities, public funds or institutions are obliged to cultivate the culture of Islamic dress in their environment". Qanun No. 5/2000 stated that every adherent of a religion other than Islam is expected to respect and adjust the clothing /dressing so as not to violate the manner and modesty in society" (Chapter 15 verse [4]). Benjamin Otto and Jan Michiel Otto said that most simple illustration related to the regulation is that "women should be dressed in accordance with Islam, which is generally interpreted as being completely covered except for their feet, hand and face. The shape of the body should not be visible through the clothes". ${ }^{45}$ This automatically excludes jeans and many other 'western-style' clothes.

43 Yogi Febriandi, "There Is No Place for Christians: The Experiences of Christian Students in Getting Access to Residence in Langsa, Aceh," in Annual International Conference on Islamic Studies XVII (2017), pp. 1-15.

44 Grossmann, "Muslim Female Activists and Sharia in Indonesia: Scopes of Acting in National and International Perspectives."

45 Benjamin Otto and Jan Michiel Otto, "Shari'a Police in Banda Aceh: Enforcement of Islam-Based Regulations and People's Perceptions," in Feener, Kloos, and Samuels (eds), Islam and the Limits of the State, p. 196. 
Many parties believe that enforcement of Islamic dress codes is not uncommon in ways that go beyond the standard of respect for human rights, whether by government officials or civil society groups in Aceh. The Wilayatul Hisbah (WH, Sharia Police) is the 'police unit' responsible for upholding the provincial sharia-based regulation, which often uses a repressive approach in performing its functions. Feener reveals, "as the most high-profile and polemicized institution of Islamic law in contemporary Aceh, the WH has been at the center of tensions between the formal legal apparatus and some sector of civil society over the promotion of shari'a standards of public morality through state programs of social control". ${ }^{46}$ Otto and Otto in ethnographic research described the pattern used by WH in conducting raids of Islamic Shari'a enforcement. ${ }^{47}$ Meanwhile, David Kloos ${ }^{48}$ and Mahdi Syihab ${ }^{49}$ discuss the phenomenon of vigilante violence by the people in order to uphold Islamic law.

Furthermore, we have reviewed the articulation of non-Muslim political rights in the realm of Islamic Sharia in Aceh. There are many articles that affirm the position of non-Muslims as second-class citizens, which is contrary to the Aceh constitution. For example, Ordinance No. 11/2006 mentions the necessity of the leader in Aceh is Muslim and to run the Islamic Shari'a (Chapter 67 verse [2]). In addition, the recruitment for the position of public leader always includes the requirement of "the ability to read the Qur'an", a matter that automatically eliminates non-Muslim citizens from the contest arena.

Sa story withdrew public attention in mid-2016. Sa, a Chinese ethnic Buddhist, became a widespread conversation for planning to run for the head village at Peukan Langsa, the only village in Langsa that has an almost equal composition of Muslim and non-Muslim

${ }^{46}$ Feener, Shari'a and Social Engineering: The Implementation of Islamic Law in Contemporary Aceh, Indonesia.

47 Otto and Otto, "Shari'a Police in Banda Aceh: Enforcement of Islam-Based Regulations and People's Perceptions."

48 David Kloos, "In the Name of Syariah? Vigilante ViolEnce, Territoriality, and Moral Authority in Aceh, Indonesia," Indonesia, 98 (2014), pp. 59-90.

49 Mahdi Syihab, "Penegakan Syariat: Etnografi Aksi Razia Santri Dayah Di Aceh Utara," in Arskal Salim and M Adlin Sila (eds), Serambi Mekah Yang Berubab: Views from Within (Jakarta: Alvabet and ARTI, 2010), pp. 57-91. 
populations. Sa told that his nomination process seemed to be disliked by many parties, ranging from village authorities, Langsa sub-district, to the provincial government. In fact, Langsa MPU (Majelis Permusyawaratan Ulama, Consultative Assembly of Ulama) issued a fatwa that "non-Muslims (infidels) should not be leaders (geuchik) in predominantly Muslim community" (Langsa MPU 2016). Moreover, in addressing the controversy of prospective candidates to non-Muslim villages, the Governor of Aceh also gave instructions that confirm the process of geuchik election in Langsa is "submissive and obedient to Islamic law". Sa ultimately withdrew from the nomination to "avoid social conflicts in society". 50

Indonesia promotes democracy, however, its realization in Aceh always faces constraints. ${ }^{51}$ In other words, though theoretically the concept of citizenship relies on the equality and freedom of each individual, the intersection with Islamic Sharia makes it more appropriate to be described as illiberal citizenship.

\section{Three Case Studies}

The analysis of agency poses a difficulty, chiefly because agency so varies in its expression and stems from causes which are opaque even to the actors. ${ }^{52}$ To show "interplay complexity between structure and agency", 53 the following sessions detail the experience of participants

\footnotetext{
50 Yogi Febriandi, "Identitas Tunggal dan Minoritas Non-Muslim di Kota Langsa," in Mohammad Iqbal Ahnaf et al. (eds), Praktik Pengelolaan Keragaman di Indonesia: Konstruksi Identitas dan Ekslusi Sosial (Yogyakarta: CRCS Universitas Gadjah Mada, 2018), pp. 133-148.

51 Myengkyo Seo, "Defining 'Religious' in Indonesia: Toward Neither an Islamic nor a Secular State," Citizenship Studies, 16, 8 (2012), pp. 1045-1058; Al Makin, "Not a Religious State': A Study of Three Indonesian Religious Leaders on the Relation of State and Religion," Indonesia and the Malay World, 46, 135 (2018), pp. 95-116.

52 Taghreed Jamal Al-deen, "Agency in Action: Young Muslim Women and Negotiating Higher Education in Australia," British Journal of Sociology of Education, 40, 5 (2019), pp. 598-613; Sumi Madhok, "Action, Agency, Coercion: Reformatting Agency for Oppressive Contexts," in Sumi Madhok, Anne Phillips, and Kalpana Wilson (eds), Gender, Agency, and Coercion (New York: Palgrave Macmillan, 2013), pp. 102-121; Holly Wardlow, Wayward Women: Sexuality and Agency in a New Guinea Society (Berkeley, London, Los Angeles: University of California Press, 2006).

53 Mitra, "Introduction: Citizenship as Cultural Flow--Shifting Paradigms, Hybridization, or Plus ca Change?"
} 
based on three case studies, namely Christian women and Islamic dress; articulation of agency in the workplace; and female Christian members of GBI Langsa.

\section{Christian Women and the Veil}

Veil and identity are often discussed scholarly based on the experience of Muslim women. ${ }^{54}$ Contrarily, the discourse of woman dress and non-Muslim women who reproduce their identity in the region that implements Islamic sharia is still not concerned by the scholars. This is in contrast to the rampant study of the veil, identity and agency of Muslim women in non-Muslim majority countries. ${ }^{55}$ To balance this academic gap, the following exposure explores the mobilization of Christian women's identity as a result of the implementation of Islamic Sharia in Aceh, placed on the discourse of citizenship and women's agencies.

Sharia in Aceh affected to the daily life of Christian women. ${ }^{56}$ The impact can be seen through Christian women response to the regulation of Islamic dress. Muhammad Ansor and Cut Intan Meutia shows that at least there are three kinds of response of Acehnese Christian women to the regulation of Islamic dress, those are (1) full time veiling; (2) part time veiling; (3) unveiled. ${ }^{57}$ The term of full time veiling is used to describe Christian women who wear veil during their activities in public spaces. While the term part time veiling is used to describe Christian women who merely wear veil at workplace.

Ria, 58 years, is the participant in the first category: full time veiling. Ria registered as a teacher in elementary school in Langsa, born

54 Fadwa El. Guindi, Veil: Modesty, Privacy and Resistance (New York: Berg, 1999); Joan Wallach Scott, The Politics of the Veil (Princeton: Princeton University Press, 2007).

55 Madeleine Chapman, "Feminist Dilemmas and the Agency of Veiled Muslim Women Analysing Identities and Social Representations," European Journal of Women's Studies, 23, 3 (2016), pp. 237-250; Manal Hamzeh, "Deveiling Body Stories: Muslim Girls Negotiate Visual, Spatial, and Ethical Hijabs," Race Ethnicity and Education, 14, 4 (2011), pp. 481-506.

56 Muhammad Ansor, "Menjadi Seperti Beragama Lain': Jilbab dan Identitas Hibrid Mahasiswi Kristen Aceh," Penamas, 29, 1 (2016), pp. 11-30; Muhammad Ansor, "Kita Kan Beda!: Persamaan Remaja Perempuan Muslim dan Kristen di Langsa, Aceh," Harmoni, 13, 2 (2014), pp. 37-50.

57 Muhammad Ansor and Cut Intan Meutia, "Jilbab dan Reproduksi Identitas Perempuan Kristen Ruang Publik Sekolah Aceh,” Kawistara, 6, 2 (2016), pp. 157-174. 
to a father who serves in a church. Therefore, she is seen as a religious Christian on one hand, on the other hand she is acculturated with the custom and local wisdom of Aceh society. Ria described herself as "a Christian with Aceh culture". Ria wears veil not only at workplace, but in all daily activities in public sphere. To her, veiling is not merely a matter of dressing, but it is her social identity in public sphere.

Ria claimed that she is the first Christian who wears veil. She wears it at her will without coercion or suggestion from others. His decision was reaping criticism. Ria said, "The Christians commented to me horribly". She ever been visited by a Christian female teacher who was at that time annoyed because she was suggested to wear veil by senior official in the Department of Education of city government. Ria was accused to be the trigger. She once debated with a Christian who criticized her because she is wearing veil. She stated: "someone told me: If my wife wears veil like this Inang (referred to me), I will return her back to her parents (divorced). I reply: you are cruel enough, you want to return your wife back to her parents just because she wear veil. [...] Factually his wife now wears veil.". (Ria 24/03/2013). Ria was criticized because she was considered being "too Islamic" in dressing style, as if she is a Muslim woman preacher (ustadzah). In pejorative way she was called "Mamah Dedeh" by several Christians. Mamah Dedeh is a popular Muslim woman preacher in the post reform Indonesia. ${ }^{58}$

The next is part time veiling, or wearing veil only at workplace. Majority of the participants are categorized as the second model. Their reasons of wearing veil are varied, some are for the reason of safety, trauma, efficiency, or of convenience considerations. Do, 60 years, wears veil since a group of people armed with long-barreled weapons during the conflict period visited the school to raid the unveiled women. Gur, 56 years, wears veil because her workplace is situated in the area of resistance movement activist basis (GAM, Gerakan Aceh Merdeka, Aceh Liberation Movement). Kes, 37 years, dan Lin, 45 years, wear veil because their profession demands to interact with people who will not accept unveiled women.

Although situated in a dominative social structure, the narrations of the participants show her ability to articulate agency. For instance,

58 Dicky Sofjan, "Gender Construction in Dakwahtainment: A Case of Hati ke Hati bersama Mamah Dedeh," Al-Jami’ah, 50, 1 (2012), pp. 57-74. 
the experience of Res. Res, 56 years, completed her high school in Banda Aceh and her diploma from Syiah Kuala University. Initially she worked as a teacher in Southeast Aceh, in a private school where the majority of the students are Chinese in ethnic. When the school was closed down, Res shifted to Banda Aceh to teach in a school where the majority of the students are also Chinese in ethnic. Some time later she was accepted as a civil servant and assigned in the school where she taught. As an alumni, Res recalled the time when she was a student. In the year 1978, most female students did not wear veil. The demand for veiling in schools began to occur in the early 1990s. After 1999, the demand getting stronger.

To Res, the reason of wearing veil can not be separated from the socio-political condition of Aceh in post-reform era. She said that after 1999 the demand to implement Islamic sharia in Aceh getting stronger. On the streets and marketplaces there is a growing demand for women to wear the veil. She witnessed a woman whose head was beaten by unknown people because she did not wear veil. She also witnessed an uncovered woman's head thrown with eggs. When shopping at the traditional market of Peunayong she often asked why did not wear veil. At the same time the conflict between the government of Indonesian and Aceh liberation movement culminated, accompanied by massive communal violence.

According to Res, such conditions shape her own traumatic experience. This condition more complicated by the fact that in her school, Res is the only Christian teacher and did not wear veil. In the beginning she tried to explain to other teachers the reason why she did not wear veil. Unfortunately the explanation was less comprehended. Res felt that she was then isolated from the social environtment of the school. She thought that wearing veil is one of the ways to be socially accepted. Around 1999 she began to wear veil. Wearing the veil changes the perception of the surrounding environment to Res. Nevertheless, the social gap between the Christian Res and others was not totally vanished.

Res confessed that her decision to wear the veil sometimes aroused dilematic situation in relation with her status as teacher for transfer knowledge and values of humanism. As a teacher of sociology (IPS, Ilmu Pengetahuan Sosial), one of subjects that she teach is diversity of Indonesian society and their freedom to express religion and cultural identity. Wearing veil, however, indicates that she does not practice the 
principles of diversity and religious freedom. When the talks in the classroom touched such theme, Res told her students that Aceh in many ways does have special situations that are different from those in other parts of Indonesia.

The third category is unveiled Christian women. Through the story of $\mathrm{Yu}, 40$ years, the authors wanted to describe another variant of Christian women agency. Yu was born and grew up in Langsa, but recently moved to Aceh Tamiang. Yu is a Christian woman, a member of Christian Protestant Batak Chruch (Huria Kristen Batak Protestan, HKBP) ini Langsa and wore veil in the first year of her probationary period for civil servant candidacy. But not long after officially became a civil servant, he did not wear the veil any longer. Yu completed her elementary and secondary education from Langsa, and bachelors from Unimed (Medan State University). Now she has completed her postgraduate in English Teaching from the same university.

Yu was accepted as candidate of civil servant in 2007, assigned to a vocational secondary school in Aceh Tamiang. In the first days of her acceptance as a candidate of civil servant, she wore the veil. During the pre-service training in Banda Aceh, Yu started to open the veil. She recounted the inner struggle that rejected the veil. Not long after being a civil servant, Yu did not wear veil while work at school. Previously $\mathrm{Yu}$ was reminded by Christian female teachers that in Aceh Tamiang there is no necessity for Christian women to wear veil. Yu's mother is a civil servant teacher at an elementary school in East Aceh. Everyday her mother wears veil at his workplace.

Yu disagrees with veiling Christian since the veil bears identity and religion. According to her calling Christian women to wear the veil is an act against the Indonesian constitution which guarantees religious freedom. To her, Acehnese Muslims have to recognize the Christians' existence, because to build Aceh needs togetherness from all elements of society from various ethnicities and religions.

\section{Making Women's Agency in the Workplace}

To establish evidence supporting our thesis, we have based this section on Nel's experience, 37 years, member of Langsa HKBP church. Nel is one of the few Christian women who work as civil servants at government office in Langsa. She started her service in 2010, and since 2013 has served as secretary of the village in Selawah (pseudonym). Nel is the third generation from the forefather who 
migrated from North Sumatera to Langsa in early days after independence. Both of her parents were born and grew up in Langsa. Nel completed her elementary education and secondary education from Langsa, gained her diploma degree from a certain university in Medan and bachelorship from Samudra University in Langsa.

Nel claimed that she is familiar with the culture of Islamic sharia. She does not object the implementation of Islamic sharia in Aceh. When she was asked about the raids of Islamic sharia enforcement, Nel said that if any Christian caught during the raid "just say we are nonMuslim, there will be no problem". Before becoming a civil servant, Nel used to wearing veil, especially when attending activities at the husband's office who is a Langsa policeman. Nel's attitude towards wearing veil cannot be separated from her backround, a Christian who was born and raised in Langsa. Nel said, "I have no obstacle with veiling, perbaps I have been accustomized to it. I wore veil at my workplace, when I went to husband's office for Bhayangkeari business. ... Although there is no coercion, it is not comfortable if I am alone who does not wear veil". (Nel 04/04/2013).

Nel described herself as "a Batak Acehnese". The phrase used by her was to affirm her integration with the culture of Aceh which is identical with Islam. Borrowing Bourdieuan perspectives, ${ }^{59}$ everyday social practices, either at home, residential neighborhood, campus, or workplace, shapped as a result of Nel's negotiation with Islamic public sphere. Nel's mother and four sisters have been wearing veil at workplaces since the implementation of Islamic sharia in Aceh. Her younger sister who works as a staff in community health center in Langsa wears veil at her workplace. Nel said, "in our family wearing veil does not a matter" (Nel 04/04/2013).

Nel's everyday experience at workplace reflected one of the variants of Christian women agency in Islamic public sphere of Aceh. As a village secretary, Nel often given the responsibility to handle some tasks related with the interest of Muslim community. Nel

59 Pierre Bourdieu, Distinction: A Social Crituque of the Judgement of Taste (Cambridge: Harvard University Press, 1984); Pierre Bourdieu, Outline of A Theory of Practice (Cambridge: Cambridge University Press, 1977); Helena Kupari, "Lifelong Minority Religion: Routines and Reflexivity: A Bourdieuan Perspective on the Habitus of Elderly Finnish Orthodox Christian Women," Religion, 46, 2 (2016), pp. 141-157; Suvi Salmenniemi, "The Making of Civil Society in Russia: A Bourdieuan Approach," International Sociology, 29, 1 (2014), pp. 38-55. 
appointed by the Head of Village to take in charge religious activities during the month of Ramadhan 2017. To undergo the task, Nel asked the assistance of her Muslim staff. This is due to the obstacle from her side, as a Christian woman, she cannot freely attend the activities during Ramadhan since it was mostly held in mosque and worship places.

During our field work, the authors did not find a more typical narrative to discuss Nel's agency except an event when she was appointed incharge of electoral committee for Tuhapeut member in Selawah village in April 2017. Tubapeut is a village institution similar to village consultative body in other parts of Indonesia. Tubapeut is a political position at the village level. It has the authority to oversee the performance of the village heads and in cooperation with village head they draft village regulation. The member of Tubapeut was elected directly by the villagers.

To smooth the activities, the committee agreed on the location of the election of Tubapeut members in the mosque or meunasah (musholla) of each hamlet. For Nel, to organize an activity at Muslim worship places is not something new though it is quite sensitive. However, to some Acehnese Muslim, the presence of non-Muslims to their worship place or vice versa, often raises the debate. In early 2015, RS, a lecturer of ar-Raniry Islamic University (Universitas Islam Negeri, UIN), became the target of public anger in Aceh for inviting dozens of students to attend interfaith discussions in the church. ${ }^{60}$ RS was even threatened to be killed after being accused of silting students' creed. Learning from this lesson, Nel always be careful in attending activities in mosques or Meunasah.

Two out of three elections were attended by Nel, those are the elections of Tuhapeut members in hamlet I and hamlet II. The location of the election in hamlet I was organized at the musholla, while in hamlet II was organized at mosque of the village. In the electoral location of hamlet I, Nel arrived when about 150s villagers have earlier crowded the musholla. The sitting position of the villagers was divided into two parts: the women sat in the inner room of the musholla, while

60 Saiful Bahri, "MIUMI Aceh Kecam Dosen UIN Ar-Raniry Pembawa Mahasiswa Ke Gereja," Dakwatuna.Com (Banda Aceh, January 9, 2015), https:www.dakwatuna.com/2015/01/09/62343/miumi-kecam-dosen-uin-ar-raniry-pembawa-mahasiswa-kegereja/\#axzz4uBvuZQqp. 
the men sat on the terrace part of the musholla. After delivering a brief instruction to the committee, the electoral process was then begun with the guidance of a man from electoral committee.

Due to technical consideration, electoral process was conducted inside the musholla. The electoral process was begun with the opening speech followed with the speech from candidates. After the session is over, the event is continued by inviting people to vote for a candidate supported by writing a name on a piece of paper prepared by the committee. It is interesting to note that during the process of activities, Nel did not enter the interior of the mosque. Nel just sat on the terrace of the musholla accompanied by her staff. During the vote count, where all the participants focused on waiting for the election results, Nel only monitored the process by standing at the door of the musholla though her body language shows a strong desire to join the committee members who were inside the musholla. Nel act (did not go inside the musholla) in the author's judgment is a form of negotiation to honor the worship place of Muslims. The attitude of not entering inside Muslim worship place, in author obervation, is not a coincidence. Nel did the same in the second location which takes place in the mosque of the village. She did not enter the mosque, and created imaginary boundaries in setting up an arena that should not be entered as a tribute to Muslims.

For Nel, paying attention to the Islamic Sharia as local wisdom in Aceh is an important aspect so that the village community may accept her presence. The avoidance of entering the mosque is Nel's negotiation, as a Christian, with an Islamic public sphere. ${ }^{61}$ The careful attention to this aspect is necessary because for most Muslims in Langsa, the existence of non-Muslim leaders is an anomaly of the Islamic Sharia state. Traditionalist society in Langsa, particularly in the village where Nel became the village secretary believe that it is the duty of the leader to give direction and guidance to common member of society in the implementation of Islamic sharia as well as other worldly matters.

${ }^{61}$ Bourdieu, Distinction: A Social Crituque of the Judgement of Taste; Bourdieu, Outline of $A$ Theory of Practice. 
Nel faces serious challenges related to the position of Secretary of the Village. Borrowing Spivak's thought, ${ }^{62}$ she faces problems in the capacities as female (gender), Christian (religion), and Batak ethnic or non-Aceh (race). Nel's identity is multi minority. As a woman, $\mathrm{Nel}$ is a minority, because the majority of the leaders in Aceh are man. Nel described herself as facing serious challenge. This is because "in Aceh, woman's chance to become a leader is somewhat hard, especially me, the nonMuslim. Even to the Muslim women it is hard, let alone the non-Muslim like me, perbaps harder..." (Nel 04/04/2013). The fact that she is Batak by ethnic is additional problem, since the majority of the villagers there are Acehnese and Javanese. Nel's meticulousness in managing identity as a Christian woman is one of the decisive factors that make him able to survive as elite bureaucrat in the village.

\section{Minority within Minority}

To discuss Christian women agency as minority within minority, we explored Mi's experience, member of Indonesian Bethel Church (GBI) in Langsa. The first author's acquaintance with Mi, 48 years, take in 2015, a few days after the city government of Langsa sealed the store house which became the worship place of Langsa GBI. Mi is a religious person and commit in practicing religion. She is the third generation from the forefathers who had migrated from China to eastern Aceh in the colonial period. Her grandfather was born in East Aceh and then shifted after independence to Langsa for business purpose. Mi and her siblings were born and brought up in Langsa. Like the majority of Chinese typical, $\mathrm{Mi}$ is one of the most successful enterpreuners in Langsa. Her business is engaged in medium size lodgement, selling automotive spare part and motorcycle workshop.

Previously, Mi was a budhist. She and her family converted to Christianity, Protestantism, precisely GBI, in 2002. Mi is the first person in Langsa who joined GBI. In the same year, two families of GBI member moved to Langsa. 15 years later (2015), the member of Langsa GBI achieves nineties (about 25 families). In the beginning, every Sunday Mi and her community of GBI joined service of worship

62 Gayatri Chakravorty Spivak, "Can the Subaltern Speak?," in Marxism and the Interpretation of Culture, ed. Cary Nelson and Lawrence Grosberg (Urbana: University Illionis Press, 1988), 294. 
in Medan. Sometimes they invited a preacher from Medan to direct service of worship in Langsa. In the end of 2002, Mi asked the permission the local village head to make her shop as a meeting place for religious activities. Mi denied that her shop had turned into a church, but merely as a gathering place for prayers (Mi 15/04/2017).

The existence of Langsa GBI began to become the hot topic among the local Muslim eminent figures in the early 2015.63 The local religious authorities like FKUB (Forum Kerukunan Umat Beragama, Forum for the Harmony of Religious Community), MPU, Islamic Sharia Department, WH and the government of Langsa, questioned the GBI activity of worship service which was conducted at a place that has no license to become a worship place. The culmination point was on Februari 25, 2015, the city government issued the letter number 450/459/2015 about the ban on the congregation of Langsa GBI to perform religious activities in that place. ${ }^{64}$ This event looks dramatic because the execution of the ban was done when members of the GBI congregation were performing worship services.

Sealing does not make the religious activity of GBI Langsa members stalled. Mi organized the shifting of worship services to house of the members of Langsa GBI in turns. But their activities did not escape the monitoring of the authorities in Langsa. When the worship services held in Sit' house, the authorities again dismissed them. The Mayor of Langsa called the Langsa GBI member to merge with Langsa HKBP. ${ }^{65}$ The Langsa HKBP accepted the member of Langsa GBI to merge with them on the condition that they have to join the liturgy with the HKBP worship procedure. Meanwhile, Mi and Langsa GBI member requested a separate worship service with a

${ }^{63}$ Anonymous, "Ruko Jadi Gereja, Warga Langsa Desak Tutup," Waspada (Medan, February 16, 2015), p. 7.

${ }^{64}$ Anonymous, "Toko Bukan Dijadikan Tempat Jualan di Langsa tapi Jadi Gereja," Global Aceb (Banda Aceh, February 18, 2015), http://www.globalaceh.com/2015/02/toko-bukan-dijadikan-tempat-jualan-di.html; Anonymous, "Muspida Langsa Segel Ruko di Jalan Iskandar Muda,” Serambi Indonesia (Banda Aceh, February 28, 2015), http://aceh.tribunnews.com/2015/02/28/muspida-langsa-segel-ruko-di-jln-iskandarmuda.

65 Anonymous, "Mupsida Minta Jemaat GBI Beribadah di Gereja," Serambi Indonesia (Banda Aceh, February 20, 2015), http://aceh.tribunnews.com/2015/02/20/muspidaminta-jemaat-gbi-beribadah-di-gereja. 
separate timetable with the HKBP worship service. While negotiations with the government and HKBP found no agreement, Mi and Langsa GBI members held a mobile service in a member's house in Aceh Tamiang, another district about $50 \mathrm{KM}$ from Langsa. At the time of Christmas, or other religious festivals, they joined the worship service in Sumatera Resort, Medan GBI (Mi 25/12/2017).

Mi does not only deal with the authority of Islamic sharia, but also with his own Protestant community, especially the Langsa HKBP. The regulation issued by the Governor No 25/2007 about the establishment of worship place in Aceh mentions the requirement to establish a new church are the number of the users reaches 140 users and the support of minimum 90 local Muslims. Since the number of Langsa GBI member was only nineties, it is administratically not covering the requirements. Moreover, the regulation was then changed and became harder, by Qanun No. 4/2016 which mentions the support of 110 local Muslims. Meanwhile, in the internal Christian itself, Mi and Langsa GBI have to face Langsa HKBP. Langsa HKBP did not approve of the proposal of Langsa GBI to hold worship service outside the official schedule of Langsa HKBP. It seems that HKBP status as ethnic based church and GBI as nationalist church which tends to be transnational contributed to the complexities of merging the two synods.

Prohibition for GBI members to perform worship activities is not the first event in Aceh. ${ }^{66}$ In 2013, the city government of Banda Aceh sealed the shophouse that became the worship place of the Banda Aceh GBI. Al-Makin holds that the assault on Bethel church in Peunayung by Muslim community is a political expression of Muslim identity in facing the rumors of Christianization. ${ }^{67}$ Likewise, the main

66 Teuku Muhammad Jaafar Sulaiman, "Robohnya Rumah Tuhan di Negeri Syariat: Perjuangan Hak Beribadah Gereja Bethel Indonesia di Kota Bandar Wisata Islam," in Praktik Pengelolaan Keragaman Di Indonesia: Kontestasi Dan Koeksistensi, ed. Mohammad Iqbal Ahnaf (Banda Aceh: CRCS Universitas Gadjah Mada, 2015), pp. 11-35; Teuku Muhammad Jaafar Sulaiman, "Dampak Qanun terhadap Eksistensi Rumah Ibadah di Aceh," in Praktik Pengelolaan Keragaman di Indonesia: Konstruksi Identitas dan Ekslusi Sosial, ed. Mohammad Iqbal Ahnaf et al. (Yogyakarta: CRCS Universitas Gadjah Mada, 2018), pp. 173-186.

67 Makin, "Islamic Acehnese Identity, Sharia, and Christianization Rumor: A Study of the Narratives of the Attack on the Bethel Church in Penauyong Banda Aceh." 
reason to the prohibiton of Langsa GBI worship activities is that the religious activity outside the worship place is the symbol of the spreading Christianization. Marzuki Hamid, the Vice-Mayor of Langsa estimated the long-term goal of Langsa GBI is to build new chuch, the thing which is contradictory to the main principle of Islamic sharia in Aceh (Hamid 10/03/2015).

The experience of $\mathrm{Mi}$ is one of Acehnese Christian women agency. The concept of agency is often used as resistancial expression to the structure or dominative norms. ${ }^{68}$ Contrary to above view, Mahmood said that "agency is not as a synonym for resistance to relations of domination, but as a capacity for action that historically specific relations of subordination". ${ }^{69}$ Mi's action can not be precisely categorized as resistance, because in same cases they were obedient to regulation. Mahmood's conception of pious agency, however, is not totally represented in Mi's narration. As a matter of fact, Mi also organized the GBI members to arrange worship service in Aceh Tamiang or sometimes in Medan. Mi's action according to Scott is hidden transcripts that is, the strategy of the loser to express the resistance through localization of obedience limited only in Langsa. ${ }^{70}$

To explain the typology of the agency expressed by $\mathrm{Mi}$, it is interesting to be explained based on the thought of Talal Asad and Holly Wardlow about the pain and responsibility as an agency. ${ }^{71} \mathrm{Mi}$ 's willingness to be involved in complex trouble and confrontative to the state, in the perspective of 'pain agency' is the kind of responsibility towards the future of the community in order to grow and develop under the rays of Christian doctrine. Mi sacrifices her energy, time,

68 Oliver P. Richmond, "Critical Agency, Resistance and a Post-Colonial Civil Society," Cooperation and Conflict, 46, 4 (2011), pp. 419-440; Maree Keating, "Rethingking Women's Resistance and Agency: The Case of Retrenched Textile Workers," Labour \& Industry: A Journal of the Social and Economic Relations of Work, 23, 2 (2013), pp. 137-149.

69 Saba Mahmood, "Feminist Theory, Embodiment, and the Docile Agent: Some Reflections on the Egyptian Islamic Revival," Cultural Anthropology, 16, 2 (2001), p. 208.

70 James C. Scott, Weapons of the Weak: Everyday Forms of Resistance (New Haven and London: Yale University Press, 1985); James C. Scott, Domination and the Arts of Resistance: Hidden Transcripts (New Haven and London: Yale University Press, 1990).

71 Talal Asad, "Agency and Pain: An Exploration," Culture and Religion: An Interdisciplinary Journal, 1, 1 (2000), pp. 29-60; Wardlow, Wayward Women: Sexuality and Agency in a New Guinea Society. 
finance, as well as her mind to ensure that her community may obtain the opportunity to practice their religion though in a difficult situation.

\section{The Multiple Agency of Christian Women}

The scholarly focus on resistance agency has been criticized for conflating the terms, and rejected for its underlying submission/resistance dichotomy. ${ }^{72}$ Likewise, the Acehnese Christian women narration shows that question of agency becomes problematic, however, in the context of Islamic public sphere the study found the limitations of agency concepts to understand the experience of interfaith relation of Christian women in Aceh.

In the introduction, the author has reviewed three models of agency, those are freedom agency, ${ }^{73}$ pious agency, ${ }^{74}$ and pious critical agency. ${ }^{75}$ In line with this, Elizabeth M. Bucar proposes "three conventional approaches to moral agency", those are autonomy, heteronomy, and theonomy. According to Bucar, the notion ofautonomy tends to "emphasize the importance of the individual in oral life and sees a woman as the source of her freedom and innovation". The notion of heteronomy "draws on post-structuralism theories in order to place women within a system of external forces and emphasizes the role of habit formation for the moral life". Finally, Bucar considers the notion of theonomy as "a possible middle ground between autonomy and heteronomy". ${ }^{76}$

\footnotetext{
72 Tanya Zion-Waldoks, "Politics of Devoted Resistance: Agency, Feminism, and Religion among Orthodox Agunah Activists in Israel," Gender \& Society, 29, 1 (2015), p. 4.

73 Butler, Gender Trouble: Feminism and the Subversion of Identity; Okin, "Is Multicult. Bad Women?"

74 Mahmood, "Feminist Theory, Embodiment, and the Docile Agent: Some Reflections on the Egyptian Islamic Revival"; Mahmood, Politics of Piety: The Islamic Revival and the Feminist Subject.

75 Rachel Rinaldo, Mobilizing Piety: Islam and Feminism in Indonesia (Oxford: Oxford University Press, 2013); Rinaldo, "Pious and Critical: Muslim Women Activists and the Question of Agency."

76 Elizabeth M. Bucar, "Dianomy: Understansing Religious Women's Moral Agency as Creative Conformity," Journal of the American Academy of Religion of Religion, 78, 3 (2010), pp. 662-686.
} 
The limitations of the concept of the three variants of the agency are seen when used to analyze the phenomenon of Christian women wearing veil in Aceh. Participant social practices related to Islamic dress regulations can not be simplified as a statement of resistance, submission, or critical submission. Even the three concepts sometimes integrated on the same subject. Ria decision to wear a veil in public space, for instance, can be explained from the mentioned three perspectives. In the perspective of submission agency, Ria attitude is the expression of submission and obedience towards the Islamic dress regulation. As the citizen of Aceh, Ria feels the need to not only respect but also selectively practice the customs of Aceh. In her opinion, "dimana bumi dipijak, di situ langit dijunjung", an Indonesian aphorism to express that wherever we live we have to adapt to local wisdom. Ria acted autonomically in the sense that the decision to wear veil comes from herself without any coercion from outsiders. Ria's autonomy over the decision even led to a subversive position on the mainstream tendency of Christian women in Aceh. Therefore, Ria reaps protests from a number of Christian women on the initiation of veiling.

The full-time veiling practiced can be explained in the discourse of "body modification". Victoria Pitts said that body modification of women cannot be merely explained as a form of subordination or subversion, but sometimes it is the expression of refashioning. ${ }^{77}$ Ria's claim that after wearing veil "my daughter said that I looked beautiful", indicates that the desire to look fashionable is one of the considerations in determining the decision to wear veil. Another participant, Ev, 22 years, a student in Unsyiah said: "When I wear veil I just see it from the perspective of fashion. I saw my friend fold their veil, I also do the same. [...] let it be like hijabers. [...] It won't make me Muslim anyway. Even it strengthen my faith. Wearing veil is just ordinary, I see it in term of fashion" (Ev, 20/12/2017).

The motivation and the meaning of wearing veil or not wearing in every individual also experienced some changes, for instance, earlier it was an expression of submission or resistance, but later it becomes

77 Victoria Pitts, In the Flesh: The Cultural Politics of Body Modification (New York: Palgrave Macmillan, 2003). 
merely a matter of fashion. ${ }^{78}$ In the beginning, Res and Fer wore veil due to trauma seeing the women become the victims of violence when they do not wear veil. But when the period of conflict ended, their reason was more encouraged by the reason of fashionable. Ev stated that wearing veil is a matter of dress style.

The exchange of motivation and meaning is not something astonishing. Because, the study on Muslim women and veiling show the transformation of meaning and concept of the veiling, some of them are as the form of resistance, ${ }^{79}$ submission, ${ }^{80}$ and identity statement or fashion. ${ }^{81}$ Some studies even show the complexities of the meaning of Muslim women's veil, which is the combination of modesty, resistance and fashion. ${ }^{82}$

78 Reina Lewis, "Veils and Sales: Muslims and the Spaces of Poscolonial Fashion Retail," Fashion Theory, 11, 4 (2007), pp. 423-442; Leila Ahmed, A Quiet Revolution: The Veil's Resurgence, from the Middle East to America (New Haven and London: Yale University Press, 2011); Guindi, Veil: Modesty, Privacy and Resistance.

79 Wolfgang Wagner, “The Veil and Muslim Women's Identity: Cultural Pressures and Resistance to Stereotyping," Culture \& Psychology, 18, 4 (2012), pp. 521-541; Guindi, Veil: Modesty, Privacy and Resistance; Scott, The Politics of the Veil.

80 Eva F Nisa, "Embodied Faith: Agency and Obedience among Face-Veiled University Students in Indonesia," The Asia Pacific Journal of Anthropology, 13, 4 (2012), pp. 366-381; John P. Bartkowski and Jen'nan Ghazal Read, "Veiled Submission: Gender, Power, and Identity Among Evangelical and Muslim Women in the United States," Qualitative Sociology, 26, 1 (2003), pp. 71-92; Vicente Llorent Bedmar and Vero'nica Cobano-Delgado Palma, "The Muslim Veil Controversy in French and Spanish Schools," Islam and Christian-Muslim Relations, 21, 1 (2010), pp. 61-73; Mahmood, Politics of Piety: The Islamic Revival and the Feminist Subject.

${ }^{81}$ Banu Gökariksel and Anna Secor, "Between Fashion and Tesettür: Marketing and Consuming Women's Islamic Dress," Journal of Middle East Women's Studies, 6, 3 (2010), pp. 118-148; Kristen Ghodsee, "The Miniskirt and the Veil: Islam, Secularism, and Women Fashion in the New Europe," Historical Reflections, 34, 3 (2008), pp. 105-125; Reina Lewis, Muslim Fashion: Contemporary Style Cultures (Durham: Duke University Press, 2015); Mona Abaza, "Shifting Landsapes of Fashion in Contemporary Egypt," Fashion Theory, 11, $2 / 3$ (2007), pp. 281-298; Carla Jones, "Fashion and Faith in Urban Indonesia," Fashion Theory, 11, 2/3 (2007), pp. 211-232; Annisa R. Beta, "Hijabers: How Young Urban Muslim Women Redefine Themselves in Indonesia," The Intenational Communication Gazette, 76, 4 (2014), pp. 377-389.

82 Nancy J. Smith-Hefner, "Javanese Women and the Veil in Post-Soeharto Indonesia," The Journal of Asian Studies, 66, 2 (2007), pp. 389-420; Dian Maya Safitri, "What Went Wrong with Veil? A Comparative Analysis of the Discourse of the Veil in France, Iran, and Indonesia," Al-Jami'ah, 48, 1 (2010), pp. 81-100; Suzanne Brenner, "Reconstructing Self and Society: Javanese Muslim Women and "The Veil," American 
The exchange of motivation and meaning can be explained through the concept of habitus that was put forward by Pierre Bourdieu. According to Bourdieu habitus is transferable across various forms of practice, thus contributing to the development of distinctive class-based lifestyles. ${ }^{83}$ The social practice of Ria is basically the result of her negotiation as a social agent with the Islamic public sphere of Aceh which is hegemonic in structure. ${ }^{84}$ Ria's experience shows the agency more than going beyond duality of resistance/submission, or autonomy/docile agency. Borrowing the statemen of Zion-Waldoks, our studies reveal that "agency is claimed through constructions of the self; the way subject act, think and speak within the dynamics of discursively demarcated spaces and allotted subject position". 85

The experience of Christian women shows that their life in Aceh on one side is always colored with repression, but on the other side provides a new opportunity to actualize themselves in the ways that are different from the common Christian woman. The repression is reflected in their daily life: the need to veil in the public sphere, limited access to employment that allows them to continue to express the desired social identity or the low freedom of religion and belief. The research has also found that participants always have a space that allows them to express the agency and escape the liminality in either gender, citizen, or Christian capacity.

\section{Conclusion}

This article has discussed Christian women agency in the Islamic public sphere, and briefly explored the context of Islamic public sphere where the research participants got the social constraints imposed by the state and constituent institutions into their lives. Christian women as a minority community in Aceh produced multiple agencies when facing critical situations. They have remained independent and were

Ethnologist, 23, 4 (1996), pp. 673-697; Nillufer Gole, The Forbidden Modern: Civilization and Veiling (Michigan: The University of Michigan Press, 1996).

83 Bourdieu, Distinction: A Social Crituque of the Judgement of Taste.

${ }^{84}$ Bourdieu, Outline of $A$ Theory of Practice; Bourdieu, Distinction: A Social Crituque of the Judgement of Taste.

85 Zion-Waldoks, "Politics of Devoted Resistance: Agency, Feminism, and Religion among Orthodox Agunah Activists in Israel." 
not easily subdued by the public sphere controlled by the values and religious identities of the majority. Acehnese Christian women had a way to articulate multiple agencies as a form of negotiation between themselves and structure.

The critical situation of these women, together with their location and special identities have simultaneously created tension, polarization, and repression alongside freedom and agency. The schism in the identity construction and their liminality of status precisely enabled them to create the third sphere from which and with which the women cope as they seek and create new power bases. Unlike the feminist scholars who conceptualized women agency as a dichotomic disposition between resistance and submission, this article has revealedthat the act of agency constitutes a dynamic varied process between power and menace in the structure of Islamic public sphere. The resistance and submission always exchange its position dynamically in a certain individual, so that it creates the definition over the social practice of Acehnese Christian women melted, variated and hard to be generalized. They used every source available, manoeuvred, moved from a social sphere, institutional, or structure that may give them the advantage to express themselves as a subject. []

\section{References}

Abaza, Mona. "Shifting Landsapes of Fashion in Contemporary Egypt." Fashion Theory, 11, no. 2/3 (2007), pp. 281-298.

Abu-Lughod, Lila. Do Muslim Women Need Saving? Cambridge: Harvard University Press, 2013.

-. "Do Muslim Women Really Need Saving? Anthropological Reflections on Cultural Relativism and Its Others." American Anthropologist, 104, no. 3 (2002), pp. 783-790.

Abu-Rabia-Queder, Sarab, and Naomi Weiner-Levy. "Between Local and Foreign Structures: Exploring the Agency of Palestinian Women in Israel." Social Politics, 20, no. 1 (2013), pp. 88-108.

Afrianty, Dina. "Local Women's NGOs and the Reform of Islamic Law in Aceh: Case of MISPI." In Islam and the Limits of the State: Reconfigurations of Practice, Community and Authority in Contemporary 
Aceh, edited by R. Michael Feener, David Kloos, and Annemarie Samuels, 118-140. Leiden: Brill, 2016.

-------. Women and Sharia Law in Northern Indonesia: Local Women's NGOs and the Reform of Islamic Law in Aceh. London: Routledge, 2015.

Ahmed, Leila. A Quiet Revolution: The Veil's Resurgence, from the Middle East to America. New Haven and London: Yale University Press, 2011.

Al-deen, Taghreed Jamal. "Agency in Action: Young Muslim Women and Negotiating Higher Education in Australia." British Journal of Sociology of Education, 40, no. 5 (July 4, 2019), pp. 598-613.

Alfian, Ibrahim. Sastra Perang: Sebuah Pembicaraan Mengenai Hikayat Perang Sabil. Jakarta: Balai Pustaka, 1992.

Anonymous. "Mupsida Minta Jemaat GBI Beribadah di Gereja." Serambi Indonesia. Banda Aceh, February 20, 2015. http://aceh.tribunnews.com/2015/02/20/muspida-mintajemaat-gbi-beribadah-di-gereja.

-. "Muspida Langsa Segel Ruko di Jalan Iskandar Muda." Serambi Indonesia. Banda Aceh, February 28, 2015. http://aceh.tribunnews.com/2015/02/28/muspida-langsasegel-ruko-di-jln-iskandar-muda.

- "Ruko Jadi Gereja, Warga Langsa Desak Tutup." Waspada. Medan, February 16, 2015.

--------. "Toko Bukan Dijadikan Tempat Jualan di Langsa tapi Jadi Gereja." Global Aceh. Banda Aceh, February 18, 2015. http://www.globalaceh.com/2015/02/toko-bukan-dijadikantempat-jualan-di.html.

Ansor, Muhammad. "Being Woman in the Land of Shari'a: Politics of the Female Body, Piety and Resistance in Langsa, Aceh." AlJami'ah, 52, no. 1 (2014), pp. 59-83.

-. “'Kita Kan Beda!': Persamaan Remaja Perempuan Muslim dan Kristen di Langsa, Aceh." Harmoni, 13, no. 2 (2014), pp. 3750 .

-. “'Menjadi Seperti Beragama Lain': Jilbab dan Identitas Hibrid Mahasiswi Kristen Aceh.” Penamas, 29, no. 1 (2016), pp. 11-30. 
"Post-Islamism and the Remaking of Islamic Public Sphere in Post-Reform Indonesia." Studia Islamika, 23, no. 3 (2016), pp. 471-515.

-. "We Are from the Same Ancestors": Christian-Muslim Relations in Contemporary Aceh Singkil."' Al-Albab, 3, no. 1 (2014), pp. 3-24.

Ansor, Muhammad, and Yaser Amri. "Beyond Pious Critical Agency: Women, Interfaith Marriage and Religious Conversion In Aceh.” Analisa, 1, no. 2 (December 21, 2016), pp. 217-238.

Ansor, Muhammad, Yaser Amri, and Ismail Fahmi Arrauf. "Under the Shadow of Sharia: Christian Muslim Relations from Acehnese Christian Experience.” Komunitas, 8, no. 1 (2016), pp. 125-134.

Ansor, Muhammad, and Cut Intan Meutia. "Jilbab dan Reproduksi Identitas Perempuan Kristen Ruang Publik Sekolah Aceh." Kawistara, 6, no. 2 (2016), pp. 157-174.

Aritonang, Jan Sihar, and Karel Steenbrink. A History of Christianity in Indonesia. Leiden and Boston: Brill, 2008.

Asad, Talal. "Agency and Pain: An Exploration." Culture and Religion: An Interdisciplinary Journal, 1, no. 1 (2000), pp. 29-60.

Avishai, Orit. "DDoing Religion' in a Secular World: Women in Conservative Religions and the Question of Agency." Gender \& Society, 22, no. 4 (2008), pp. 409-433.

Bahri, Saiful. "MIUMI Aceh Kecam Dosen UIN Ar-Raniry Pembawa Mahasiswa ke Gereja." Dakwatuna.Com. Banda Aceh, January 9, 2015. https:www.dakwatuna.com/2015/01/09/62343/miumikecam-dosen-uin-ar-raniry-pembawa-mahasiswa-kegereja/\#axzz4uBvuZQqp.

Bartkowski, John P., and Jen'nan Ghazal Read. "Veiled Submission: Gender, Power, and Identity Among Evangelical and Muslim Women in the United States." Qualitative Sociology, 26, no. 1 (2003), pp. 71-92.

Bautista, Julius. "The Meta-Theory of Piety: Reflections on the Work of Saba Mahmood." Contemporary Islam, 2, no. 1 (2008), pp. 7583. 
Bedmar, Vicente Llorent, and Verónica Cobano-Delgado Palma. "The Muslim Veil Controversy in French and Spanish Schools." Islam and Christian-Muslim Relations, 21, no. 1 (2010), pp. 61-73.

Beta, Annisa R. "Hijabers: How Young Urban Muslim Women Redefine Themselves in Indonesia." The Intenational Communication Gazette, 76, no. 4 (2014), pp. 377-389.

Bourdieu, Pierre. Distinction: A Social Crituque of the Judgement of Taste. Cambridge: Harvard University Press, 1984.

---------. Outline of $A$ Theory of Practice. Cambridge: Cambridge University Press, 1977.

Brenner, Suzanne. "Reconstructing Self and Society: Javanese Muslim Women and 'The Veil."' American Ethnologist, 23, no. 4 (1996), pp. 673-697.

Bucar, Elizabeth M. "Dianomy: Understansing Religious Women's Moral Agency as Creative Conformity." Journal of the American Academy of Religion of Religion, 78, no. 3 (2010), pp. 662-686.

Bustamam-Ahmad, Kamaruzzaman. "The Application of Islamic Law in Indonesia: The Case Study of Aceh." Journal of Indonesian Islam, 1, no. 1 (2007), pp. 135-180.

Butler, Judith. Exitable Speech: A Politics of Pervormative. New York: Routledge, 1997.

--------. Gender Trouble: Feminism and the Subversion of Identity. New York: Taylor and Francis e-Library, 1999.

Chapman, Madeleine. "Feminist Dilemmas and the Agency of Veiled Muslim Women Analysing Identities and Social Representations." European Journal of Women's Studies, 23, no. 3 (2016), pp. 237-250.

Crouch, Melissa. "Implementing the Regulation on Places of Worship in Indonesia: New Problems, Local Politics and Court Action." Asian Studies Review, 34, no. 4 (2010), pp. 403-419.

Fasya, Teuku Kemal. "Memperbaiki Keberagamaan Singkil." Kompas. Jakarta, 2015.

Febriandi, Yogi. "Identitas Tunggal dan Minoritas Non-Muslim di Kota Langsa." In Praktik Pengelolaan Keragaman di Indonesia: Konstruksi Identitas dan Ekslusi Sosial, edited by Mohammad Iqbal Ahnaf, Trisno Sutanto, Subandri Simbolon, and Azin Anwar 
Fachrudin, 133-148. Yogyakarta: CRCS Universitas Gadjah Mada, 2018.

. "There is No Place for Christians: The Experiences of Christian Students in Getting Access to Residence in Langsa, Aceh." In Annual International Conference on Islamic Studies XVII, 1-15, 2017.

Feener, R. Michael. Shari'a and Social Engineering: The Implementation of Islamic Law in Contemporary Aceh, Indonesia. Oxford: Oxford University Press, 2013.

------. "State Shari'a and Its Limits." In Islam and the Limits of the State: Reconfigurations of Practice, Community and Authority in Contemporary Aceh, edited by R. Michael Feener, David Kloos, and Annemarie Samuels, 1-23. Leiden: Brill, 2016.

Fleetwood, Jennifer. "Narrative Habitus: Thinking through Structure/Agency in the Narratives of Offenders." Crime Media Culture, 12, no. 2 (2016), pp. 173-192.

Ghodsee, Kristen. "The Miniskirt and the Veil: Islam, Secularism, and Women Fashion in the New Europe." Historical Reflections, 34, no. 3 (2008), pp. 105-125.

Giddens, Anthony. The Constitution of Society: Outline of the Theory of Structuration. Cambridge: Polity Press, 1984.

Gökariksel, Banu, and Anna Secor. "Between Fashion and Tesettür: Marketing and Consuming Women's Islamic Dress." Journal of Middle East Women's Studies, 6, no. 3 (2010), pp. 118-148.

Gole, Nillufer. The Forbidden Modern: Civilization and Veiling. Michigan: The University of Michigan Press, 1996.

Grayman, Jesse Hession. "Humanitarian Encounters in Post-Conflict Aceh, Indonesia.” Harvard University, 2012.

--. "We Build Our Own Stories': The 19-Th-Century Figure and 21st-Century Myth of the Acehnese Poet Dokarim." Indonesia, 99 (2015), pp. 51-65.

Grossmann, Kristina. "Muslim Female Activists and Sharia in Indonesia: Scopes of Acting in National and International Perspectives." Review of Indonesian and Malaysian Affairs, 48, no. 1 (2014), pp. 95-125. 
. "Women's Rights Activists and the Drafting Process of the Islamic Criminal Law Code (Qanun Jinayat)." In Islam and the Limits of the State: Reconfigurations of Practice, Community and Authority in Contemporary Aceh, edited by R. Michael Feener, David Kloos, and Annemarie Samuels, 87-117. Leiden: Brill, 2016.

Guindi, Fadwa El. Veil: Modesty, Privacy and Resistance. New York: Berg, 1999.

Hamzeh, Manal. "Deveiling Body Stories: Muslim Girls Negotiate Visual, Spatial, and Ethical Hijabs." Race Ethnicity and Education, 14, no. 4 (2011).

Ichwan, Moch. Nur. "Official Ulema and the Politics of ReIslamization: The Majelis Permusyawaratan Ulama, Shariatization and Contested Authority in Post-New Order Aceh." Journal of Islamic Studies, 22, no. 2 (2011), pp. 183-214.

Idria, Reza. "Cultural Resistance to Shariatism in Aceh." In Islam, Politics and Change: The Indonesian Experience after the Fall of Subarto, edited by Kees van Dijk and Nico J.G. Kaptein, 247-268. Leiden: Leiden University Press, 2016.

Janoschka, Michael. "Habitus and Radical Reflexivity: A Conceptual Approach to Study Political Articulations of Lifestyle- and Tourism- Related Mobilities." Journal of Policy Research in Tourism, Leisure \& Events, 3, no. 3 (2011), pp. 224-236.

Jones, Carla. "Fashion and Faith in Urban Indonesia." Fashion Theory, 11 , no. $2 / 3$ (2007), pp. 211-232.

Keating, Maree. "Rethingking Women's Resistance and Agency: The Case of Retrenched Textile Workers." Labour \& Industry: A Journal of the Social and Economic Relations of Work, 23, no. 2 (2013), pp. 137-149.

Kloos, David. Becoming Better Muslims: Religious Authority and Ethical Improvement in Aceh, Indonesia. Princeton and Oxford: Princeton University Press, 2018.

--. "In the Name of Syariah? Vigilante Violence, Territoriality, and Moral Authority in Aceh, Indonesia." Indonesia, 98 (2014), pp. 59-90. 
Kupari, Helena. "Lifelong Minority Religion: Routines and Reflexivity: A Bourdieuan Perspective on the Habitus of Elderly Finnish Orthodox Christian Women.” Religion, 46, no. 2 (2016), pp. 141157.

Kymlicka, Will. Multicultural Citizenship: A Liberal Theory of Minority Rights. New York: Oxford University Press, 1995.

Lewis, Reina. Muslim Fashion: Contemporary Style Cultures. Durham: Duke University Press, 2015.

. "Veils and Sales: Muslims and the Spaces of Poscolonial Fashion Retail.” Fashion Theory, 11, no. 4 (2007), pp. 423-442.

Madhok, Sumi. "Action, Agency, Coercion: Reformatting Agency for Oppressive Contexts." In Gender, Agency, and Coercion, edited by Sumi Madhok, Anne Phillips, and Kalpana Wilson, 102-121. New York: Palgrave Macmillan, 2013.

Mahmood, Saba. "Feminist Theory, Embodiment, and the Docile Agent: Some Reflections on the Egyptian Islamic Revival." Cultural Anthropology, 16, no. 2 (2001), pp. 202-236.

------. Politics of Piety: The Islamic Revival and the Feminist Subject. Princeton: Princeton University Press, 2005.

Makin, Al. "Islamic Acehnese Identity, Sharia, and Christianization Rumor: A Study of the Narratives of the Attack on the Bethel Church in Penauyong Banda Aceh." Journal of Indonesian Islam, 10, no. 01 (2016), pp. 1-36.

-. "Not a Religious State': A Study of Three Indonesian Religious Leaders on the Relation of State and Religion." Indonesia and the Malay World, 46, 135 (2018), pp. 95-116.

Miswari. "Mu'ḍilat Al-Aqlīyah Al-Masīhīyah Fī Hudūd Balad AlSharī‘ah Al-Islāmìyah.” Studia Islamika, 25, no. 2 (2018), p. 351.

Mitra, Subrata K. "Introduction: Citizenship as Cultural Flow-Shifting Paradigms, Hybridization, or Plus ca Change?” In Citizenship as Cultural Flow: Structure, Agency and Power, edited by Subrata K. Mitra, 1-21. London: Springer, 2013.

Mujiburrahman. Feeling Threatened: Muslim-Christian Relations in Indonesia's New Order. Leiden: Amsterdam University Press, 2006. 
Nisa, Eva F. "Embodied Faith: Agency and Obedience among FaceVeiled University Students in Indonesia." The Asia Pacific Journal of Anthropology, 13, no. 4 (2012), pp. 366-381.

Okin, Susan Moller. "Is Multiculturalism Bad for Women?" In Is Multiculturalism Bad for Women?, edited by Joshua Cohen, Matthew Howard, and Martha C. Nussbaum, 7-26. Princeton: Princeton University Press, 1999.

Otto, Benjamin, and Jan Michiel Otto. "Shari'a Police in Banda Aceh: Enforcement of Islam-Based Regulations and People's Perceptions." In Islam and the Limits of the State: Reconfigurations of Practice, Community and Authority in Contemporary Aceh, edited by R. Michael Feener, David Kloos, and Annemarie Samuels, 185-213. Leiden: Brill, 2016.

Pitts, Victoria. In the Flesh: The Cultural Politics of Body Modification. New York: Palgrave Macmillan, 2003.

Richmond, Oliver P. "Critical Agency, Resistance and a Post-Colonial Civil Society." Cooperation and Conflict, 46, no. 4 (2011), pp. 419440.

Rinaldo, Rachel. Mobilizing Piety: Islam and Feminism in Indonesia. Oxford: Oxford University Press, 2013.

--------. "Pious and Critical: Muslim Women Activists and the Question of Agency." Gender \& Society, 20, no. 10 (2014), pp. 123.

-------. "Women and Piety Movements." In The New Blackwell Companion to the Sociology of Religion, edited by Bryan S. Turner, 584-605. United Kingdom: Wiley-Blackwell, 2010.

Ropi, Ismatu. "Muslim-Christian Polemics in Indonesian Islamic Literature." Islam and Christian-Muslim Relations, 9, no. 2 (1998), pp. 217-229.

--------. Religion and Regulation in Indonesia. Singapore: Palgrave Macmillan, 2017.

Safitri, Dian Maya. "What Went Wrong With Veil? A Comparative Analysis of the Discourse of the Veil in France, Iran, and Indonesia." Al-Jami'ah, 48, no. 1 (2010), pp. 81-100.

Salim, Arskal. Challenging the Secular State: The Islamization of Law in Modern Indonesia. Honolulu: University of Hawai'i Press, 2008. 
."'Sharia from below' in Aceh (1930s-1960s): Islamic Identity and the Right to Self-Determination with Comparative Reference to the Moro Islamic Liberation Front (MILF)." Indonesia and the Malay World, 32, no. 92 (2004), pp. 80-99.

Salmenniemi, Suvi. "The Making of Civil Society in Russia: A Bourdieuan Approach." International Sociology, 29, no. 1 (January 12, 2014), pp. 38-55.

Scott, James C. Domination and the Arts of Resistance: Hidden Transcripts. New Haven and London: Yale University Press, 1990.

- Weapons of the Weak: Everyday Forms of Resistance. New Haven and London: Yale University Press, 1985.

Scott, Joan Wallach. The Politics of the Veil. Princeton: Princeton University Press, 2007.

Scott, Rachel M. The Challenge of Political Islam: Non-Muslims and the Egyptian State. Stanford, California: Stanford University Press, 2010.

Scott, Rachel M. "Contextual Citizenship in Modern Islamic Thought." Islam and Christian-Muslim Relations, 18, no. 1 (2007), pp. 1-18.

Seo, Myengkyo. "Defining 'Religious' in Indonesia: Toward Neither an Islamic nor a Secular State." Citizenship Studies, 16, no. 8 (2012), pp. 1045-1058.

Setiawan, Deny, and Bahrul Khoir Amal. "Membangun Pemahaman Multikultural dan Multiagama Guna Menangkal Radikalisme di Aceh Singkil." Al-Ulum, 16, no. 2 (2016), pp. 348-367.

Siregar, Hasnil Basri. "Lessons Learned from the Implementation of Islamic Shari'ah Criminal Law in Aceh, Indonesia." Journal of Law and Religion, 24, no. 1 (2008), pp. 143-176.

Smith-Hefner, Nancy J. "Javanese Women and the Veil in PostSoeharto Indonesia." The Journal of Asian Studies, 66, no. 2 (2007), pp. 389-420.

Sofjan, Dicky. "Gender Construction in Dakwahtainment: A Case of Hati Ke Hati Bersama Mamah Dedeh." Al-Jami'ah, 50, no. 1 (2012), pp. 57-74.

Spivak, Gayatri Chakravorty. "Can the Subaltern Speak?” In Marxism and the Interpretation of Culture, edited by Cary Nelson and 
Lawrence Grosberg, 271-313. Urbana: University Illionis Press, 1988.

Sulaiman, Teuku Muhammad Jaafar. "Dampak Qanun terhadap Eksistensi Rumah Ibadah di Aceh." In Praktik Pengelolaan Keragaman di Indonesia: Konstruksi Identitas dan Ekslusi Sosial, edited by Mohammad Iqbal Ahnaf, Trisno Sutanto, Subandri Simbolon, and Aziz Anwar Fachrudin, 173-186. Yogyakarta: CRCS Universitas Gadjah Mada, 2018.

-. "Robohnya Rumah Tuhan di Negeri Syariat: Perjuangan Hak Beribadah Gereja Bethel Indonesia di Kota Bandar Wisata Islam." In Praktik Pengelolaan Keragaman di Indonesia: Kontestasi dan Koeksistensi, edited by Mohammad Iqbal Ahnaf, 11-35. Banda Aceh: CRCS Universitas Gadjah Mada, 2015.

Syihab, Mahdi. "Penegakan Syariat: Etnografi Aksi Razia Santri Dayah di Aceh Utara." In Serambi Mekah yang Berubah: Views from Within, edited by Arskal Salim and M Adlin Sila, 57-91. Jakarta: Alvabet and ARTI, 2010.

Taylor, Reed. "Syariah as Heterotopia: Responses from Muslim Women in Aceh, Indonesia." Religions, 6, no. 2 (2015), pp. 566593.

Taylor, Reed W. “A Postcolonial Inquiry of Women’s Political Agency in Aceh, Indonesia: Towards a Muslim Feminist Approach?" Virginia Polytechnic Institute and State University, 2012.

Veer, Paul van 't. Perang Aceh: Kisah Kegagalan Snouck Hurgronje. Jakarta: Grafiti Press, 1985.

Wagner, Wolfgang. “The Veil and Muslim Women's Identity: Cultural Pressures and Resistance to Stereotyping." Culture \& Psychology, 18, no. 4 (2012), pp. 521-541.

Wardlow, Holly. Wayward Women: Sexuality and Agency in a New Guinea Society. Berkeley, London, Los Angeles: University of California Press, 2006.

Zion-Waldoks, Tanya. "Politics of Devoted Resistance: Agency, Feminism, and Religion among Orthodox Agunah Activists in Israel." Gender \& Society, 29, no. 1 (2015), pp. 73-97. 